TAHKIM, Jurnal Peradaban dan Hukum Islam. Vol.3 No.l (Maret, 2020) | ISSN : 2597-7962

\title{
PENERAPAN KAIDAH-KAIDAH FIQIH DALAM TRANSAKSI EKONOMI DI LEMBAGA KEUANGAN SYARIAH
}

\author{
Iwan Permana \\ Fakultas Syariah Universitas Islam Bandung \\ iwanpermana@unisba.ac.id
}

\begin{abstract}
ABSTRAK
Kaidah-kaidah fiqh lahir dari al-quran, al-hadis, dan ijma'. Kaidah-kaidah fiqih lahir dengan tujuan menetapkan hukum Islam dalam persoalan-persoalan baru yang terus berkembang seiring perkembangan zaman, terkhusus dalam transaksi ekonomi atau muamalah maliyah yang senantiasa berkembang di lembaga keuangan syariah. Dengan demikian kaidah-kaidah fiqh merupakan produk ijtihad dan merupakan generalisasi dari tema-tema fiqh yang tersebar di kalangan ulama mazhab. Adanya kaidah-kaidah fiqh merupakan suatu keharusan untuk memperoleh kemudahan mengetahui hukumhukum kontemporer terkhusus persoalan ekonomi yang banyak tidak memiliki nash sharîh (dalil pasti) dalam al-quran maupun hadits. Begitu pula untuk mempermudah menguasai permasalahan furu'iyyah (cabang) yang terus berkembang dan tidak terhitung jumlahnya terkhusus dalam persoalan ekonomi yang berkembang di lembaga keuangan syariah.
\end{abstract}

Kata Kunci: Transaksi, Ekonomi, Kaidah, Fiqih.

\begin{abstract}
The principles of fiqh are born from the Qur'an, al-hadith, and ijma'. The principles of jurisprudence were born with the aim of establishing Islamic law in new issues that continue to develop along with the times, especially in economic transactions or muamalah maliyah which is always developing in Islamic financial institutions. Thus the principles of figh are the products of ijtihad and are generalizations of fiqh themes that are spread among the school of ulemas. The existence of the rules of figh is a necessity to obtain the ease of knowing contemporary laws, especially economic issues, many of which do not have a sharîh text (a definite proposition) in the Qur'an or hadith. Similarly, to make it easier to master the problems of furu'iyyah (branches) that continue to grow and countless, especially in economic problems that develop in Islamic financial institutions.
\end{abstract}

Keywords: Transactions, Economy, Rules, fiqh 


\section{A. PENDAHULUAN}

Sebagai landasan aktivitas umat Islam sehari-hari dalam usaha memahami maksud-maksud ajaran Islam (maqashid al-syari'ah) secara lebih menyeluruh, keberadaan qawaid Fiqhiyyah menjadi sesuatu yang amat penting. Baik dimata para ahli ushul maupun fuqaha, pemahaman terhadap qawa'id Fiqhiyyah adalah mutlak diperlukan untuk melakukan suatu ijtihad atau pembaruan pemikiran dalam masalah ibadah, muamalah, dan skala prioritas. Banyak kaidah fikih yang ruang lingkup dan cakupannya lebih sempit dan isi kandungannya lebih sedikit. Kaidah yang semacam ini hanya berlaku dalam cabang-cabang fiqih tertentu dan disebut al-qawaid al fiqhiyyah al-khashshah atau juga disebut al-dhawabith oleh sebagian ulama.

Manfaat keberadaan qawa'id fiqhiyyah adalah untuk menyediakan panduan yang lebih praktis yang diturunkan dari teks dan jiwa nash asalnya yaitu al-Qur'an dan alHadis yang digeneralisasi dengan sangat teliti oleh para ulama terdahulu dengan memperhatikan berbagai kasus fiqh yang pernah terjadi, sehingga hasilnya kini mudah diterapkan kepada masyarakat luas.

Menurut Musthafa al-Zarqa, Qowaidul Fiqhiyyah ialah dasar-dasar fiqh yang bersifat umum dan bersifat ringkas berbentuk undang-undang yang berisi hukumhukum syara' yang umum terhadap berbagai peristiwa hukum yang termasuk dalam ruang lingkup kaidah tersebut. ${ }^{1}$

Hukum dasar dalam fiqh muamalah merupakan asas yang dapat dikatakan sebagai teori yang membentuk hukum-hukum dalam bidang ekonomi. Dr Abbas Arfan dalam bukunya 99 kaidah fiqh muamalah kulliyah menuliskan lima asas: ${ }^{2}$

1. Asas pertama adalah Taba'dul al-Mana'fi yaitu segala bentuk kegiatan muamalah harus memberikan keuntungan dan manfaat bagi pihak-pihak yang terlibat.

2. Asas kedua adalah asas pemerataan dan keadilan yaitu asas yang berupa prinsip keadilan dalam bidang muamalah yang menghendaki agar harta tidak hanya dikuasai oleh segelintir orang sehingga harta itu harus didistribusikan secara merata diantara masyarakat baik kaya maupun miskin.

${ }^{1}$ Abd. Rahman Dahlan, Ushul Fiqih. (Jakarta: Amzah, 2005) hlm. 13.

2 Abbas Arfan, 99 Kaidah Fiqh Muamalah Kulliyah, (Malang : UIN Maliki Press, 2013), hlm.103-105. 
3. Asas ketiga adalah keridaan dan kerelaan, asas ini menyatakan bahwa setiap bentuk muamalat antar muslim atau antar pihak harus berdasarkan kerelaan masing-masing.

4. Asas keempat yaitu tidak adanya penipuan atau dapat dikatakan asas kejujuran dalam bertransaksi.

5. Asas kelima yaitu asas kebaikan dan ketaqwaan yang dalam hal ini muslim harus melakukan segala hal untuk kebaikan dan peningkatan ketaqwaannya kepada Allah SWT.

Islam sangat memperhatikan perekonomian umatnya, hal ini dapat dilihat dari banyaknya ayat-ayat Al-quran, Sunah, maupun Ijtihad para ulama yang berbicara tentang perekonomian. Bahkan ayat yang terpanjang dalam Alquran justru berisi tentang masalah perekonomian, bukan masalah ibadah mahdhah atau akidah. Ayat yang terpanjang itu ialah ayat 282 dalam surah al-Baqarah, menurut Ibn 'Arabi ayat ini mengandung 52 hukum ekonomi. Alquran sebagai pegangan hidup umat Islam telah mengatur kegiatan bisnis secara eksplisit, dan mengandung bisnis sebagai sebuah pekerjaan yang menguntungkan dan menyenangkan, sehingga Alquran sangat mendorong dan memotivasi umat Islam untuk melakukan transaksi bisnis dalam kehidupan mereka. ${ }^{3}$

\section{B. METODE PENELITIAN}

Metode yang digunakan dalam penelitian ini adalah metode kualitatif dengan menggunakan pendekatan deskriptif analisis yang bertujuan untuk memberikan gambaran tentang kaidah-kaidah fiqih dengan praktek transaksi ekonomi di lembaga keuangan syariah. Adapun teknik pengumpulan data yaitu dengan cara mengumpulkan kaidah-kaidah fiqih dan dhawabith fiqhiyyah ${ }^{4}$ terkait dengan muamalah maliyah untuk diterapkan dalam transaksi ekonomi di lembaga keuangan syariah.

${ }^{3}$ Muhammad Ali al-Sayid, Tafsir Ayat al-Ahkam, Juz. 2, (Bayrut: Dâr al-Fikr, 1996), hlm. 86

${ }^{4}$ Dhawabith Fiqhiyyah sering digunakan oleh ulama fiqih untuk menyebut qaidah fiqih yang khas (spesifik) berkaitan langsung mengenai masalah tertentu. 


\section{PEMBAHASAN}

Qawaid (قواعد) adalah jamak dari kata qoidah (قاعدة). Dan secara etimologi bermakna asas (اساس) yang berarti pangkal, dasar, asas dari segala sesuatu. ${ }^{5}$

Dan Fiqih الفقه adalah faham atau tahu. Menurut istilah yang digunakan para ahli Fiqh (fuqaha). Fiqh itu ialah ilmu yang menerangkan hukum-hukum syari'at Islam yang diambil dari dalil-dalilnya yang terperinci. ${ }^{6}$

Menurut al-Zarqa', fiqih secara istilah adalah putusan-putusan umum yang biasanya mencakup sebagian besar dari bagian-bagiannya. ${ }^{7}$

Sedangkan muamalah معاملة secara bahasa berasal dari kata عامل - يعامل - معاملة yang artinya saling bertindak, saling berbuat dan saling mengamalkan. Sedangkan menurut istilah Muamalah adalah tukar menukar barang atau sesuatu yang memberi manfaat dengan cara yang ditentukan. Bila dihubungkan dengan lafaz fiqh, mengandung arti aturan yang mengatur hubungan antara seseorang dengan orang lain dalam pergaulan hidup di dunia. ${ }^{8}$

Dalam kehidupan muamalah maliyah, pemakaian qawa'id fiqhiyyah menjadi sesuatu yang sangat penting. Seiring perkembangan zaman, keperluan adanya qaidah yang lebih banyak tampaknya tidak dapat dihindarkan. ${ }^{9}$

Banyak sekali usaha manusia yang berhubungan dengan barang dan jasa. Sudah tentu dengan perkembangan ilmu dan teknologi, serta tuntutan masyarakat yang semakin meningkat, melahirkan model transaksi baru yang membutuhkan penyelesaiannya dari sisi hukum Islam yang bersumber dari al-Qur'an dan as-sunah. Pemikiran lain sumber hukum Islam sesudah as-sunah adalah ijma' ${ }^{10}$. Sesudah ijma' adalah qiyas yang kemudian lahir kaidah-kaidah fiqih untuk menjawab dan

5 Azat Ubaid ad-Da'asi, al-Qawaid al-Fiqhiyyah ma'a syarhi al-Mujaz, (Damaskus: dar atTarmizi. 1989) cet. 3, hlm. 7.

${ }^{6} \mathrm{Ibid}, \mathrm{hlm} 7$.

${ }^{7}$ Syaikh ahmad bin syaikh muhammad al-Zarqa', syarhu al-Qawaid al-Fiqhiyyah, (Damaskus: dar al-Qalam 1989), cet. 2, hlm 33.

8 http://www.psycholovegy.com/2012/05/pengertian-dan-ruang-lingkup-fiqh.html diakses 20 januari 2020

${ }^{9}$ Toha Andiko, Ilmu Qawa'id Fiqhiyyah : Panduan Praktis dalam Merespon Problematika Hukum Islam, (Yogyakarta : Teras, 2011), hlm. 160-161.

${ }^{10}$ Siska Lis Sulistiani, Perbandingan Sumber Hukum Islam, TAHKIM, Jurnal Peradaban dan Hukum Islam. Vol. 1 No. 1 (Maret, 2018), hlm. 114. 
menyelesaikan persoalan-persoalan kehidupan yang terus berkembang seiring perkembangan zaman.

Penyelesaian yang Islami dan mampu menyelesaikan masalah-masalah kehidupan yang nyata, sudah tentu caranya adalah dengan menggunakan kaidah-kaidah berikut: ${ }^{11}$

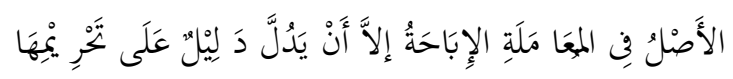

\section{"Hukum asal dalam semua bentuk muamalah adalah boleh dilakukan kecuali ada dalil} yang mengharamkannya"

Maksud kaidah ini adalah bahwa dalam setiap muamalah dan transaksi, pada dasarnya boleh, seperti jual beli, sewa menyewa, gadai, kerja sama (mudharabah atau musyarakah), perwakilan (wakalah), dan lain-lain, kecuali yang tegas diharamkan seperti mengakibatkan kemudaratan seperti tipuan (tadlis), ketidakpastian (taghrir), perjudian dan riba. ${ }^{12}$

Dalam transaksi ekonomi di lembaga keuangan syariah, tidak lepas dari akad Musyārakah, ${ }^{13}$ Mudhārabah, ${ }^{14}$ Murābahah ${ }^{15}$, musawamah, ${ }^{16}$ ijarah, ${ }^{17}$ wakalah, ${ }^{18}$ Musahamah, ${ }^{19}$ Wadi'ah, $^{20}$ dan banyak lagi akad dan konsep ekonomi di lembaga

${ }^{11}$ A. Djazuli, Kaidah-Kaidah Fikih, (Jakarta: Kencana, 2006), hlm. 129.

${ }^{12}$ Ibid., hlm. 130.

${ }^{13}$ Musyārakah adalah akād kerjasama antara dua pihak atau lebih untuk suatu usaha tertentu dimana masing-masing pihak memberikankontribusi dana yang di sepakati. Muhammad Syafi'I Antonio, Bank Syari'ah dari Teori ke Praktek (Jakarta : Gema Insani, 2001), hlm. 90.

14 Mudhārabah adalah sebuah akad kerjasama antaradua pihak dimana pihak pertamamenyediakan dana $100 \%$ dan sedangkan pihak lain menjadi pengelola. Muhammad Syafi'i Antonio, Bank Syari'ah dari Teori ke Praktek......hlm. 95.

${ }^{15}$ Murābah ah didefinisikan oleh para Fuqaha sebagai penjualan barang seharga biaya atau harga pokok cost barang tersebut ditambah mark-up atau margin keuntungan yang di sepakati. Wiroso, Jual Beli Murābah ah, (Yogyakarta: UII Press, 2005), hlm.13.

${ }^{16}$ Musawamah adalah akad jual bell biasa dimana penjual memasang harga tanpa member tahu si pembeliberapa margin keuntungan. Muhamad,Sistem dan Prosedur Operasional Bank Syari'ah, (Yogyakarta: UII Pres, 2000), hlm. 23.

${ }^{17}$ Ijârah adalah transaksi terhadap suatu manfaat dengan imbalan atau transaksi terhadap suatu manfaat yang dituju, tertentu dengan imbalan yang disepakati. Muhamad,Sistem dan Prosedur Operasional Bank Syari'ah,.... hlm. 34.

18 Wakalah adalah pendelegasian wewenang seseorang kepada orang lain baik secara mutlak maupun dengan syarat tertentu. Ismail, Perbankan Syari'ah, (Jakarta : Kencana Media Group, 2011), hlm. 194.

${ }^{19}$ Musâhamah adalah saling memberikan modal atau saham atau dengan bahasa lain bahwa sebagian saham perusahaan yang diperjualbelikan kepada masyarakat dengan ketentuan bahwa imbalan yang diberikan kepada pemilik modal sesuai dengan prosentase modal masing masing dalam suatu perusahaan dan dibayarkan pada waktu yang telah ditentukan. Abdul Aziz Dahlan, Ensiklopedi Hukum Islam, Jilid IV, (Jakarta: Ichtiar Baru van Houve, 1997), hlm. 1244. 
keuangan syariah yang dimana konsep tersebut ditetapkan dan disepakati atas kaidahkaidah fiqih.

Adapun kaidah kaidah fiqih yang diterapkan dalam transaksi ekonomi di lembaga keuangan syariah sebagai berikut:

\section{Kaidah - kaidah Fiqh dalam Transaksi ('Aqad)}

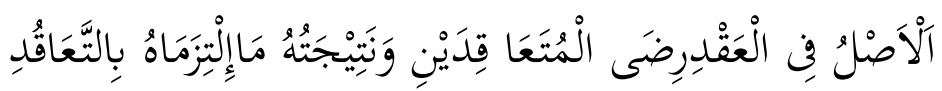

"Hukum pokok pada akad adalah kerelaan kedua belah pihak yang mengadakan akad dan hasilnya apa yang salingditentukan dalam akad tersebut.

Maksud kaidah diatas adalah bahwa setiap transaksi harus didasarkan atas kebebasan dan kerelaan, tidak ada unsur paksaan atau kekecewaan salah satu pihak, bila itu terjadi maka transaksinya tidak sah. ${ }^{21}$ Contohnya pembeli yang merasa tertipu karena dirugikan oleh penjual karena barangnya terdapat cacat yang disembunyikan.

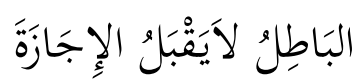

"Akad yang batal tidak menjadi sah karena dibolehkan"

Akad yang batal dalam hukum Islam dianggap tidak ada atau tidak pernah terjadi. Oleh karena itu, akad yang batal tetap tidak sah walaupun diterima oleh salah satu pihak. $^{22}$ Contohnya, lembaga keuangan syariah tidak boleh melakukan akad dengan lembaga keuangan lain yang menggunakan sistem bunga, meskipun sistem bunga dibolehkan oleh pihak lain, karena sistem bunga sudah dinyatakan haram oleh DSN, akad baru sah apabila lembaga keuangan lain mau menggunakan akad yang diberlakukan pada lembaga keuangan syariah, yaitu akad atau transaksi tanpa menggunakan sistem bunga.

${ }^{20}$ Wadi'ah adalah menitipkan sesuatu kepada orang lain dengan berdasarkan amanah atau kepercayaan agar dijaga dengan sebaik-baiknya dan dipelihara dengan semestinya. M. Abdul Mujib, Kamus Istilah Fikih, (Jakarta: Pustaka Firdaus, 1994), hlm 410.

${ }^{21}$ Muhlish Usman, Kaidah-Kaidah Ushuliyah dan Fiqhiyyah, (Jakarta : Rajawali Pers, 1993), hlm.184.

${ }^{22}$ A. Djazuli, Kaidah.. hlm. 131. 


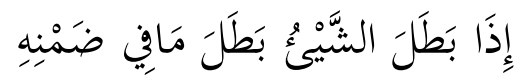

“Apabila sesuatu akad batal, maka batal pula yang ada dalam tanggungannya."

Contohnya, penjual dan pembeli telah melaksanakan akad jual beli. Si pembeli telah menerima barang dan si penjual telah menerima uang. Kemudian kedua belah pihak membatalkan jual beli tadi. Maka, hak pembeli terhadap barang menjadi batal dan hak penjual terhadap harga barang menjadi batal. Artinya, si pembeli harus mengembalikan barangnya dan si penjual harus mengembalikan uang (harga barangnya).

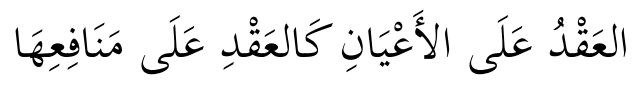

"Akad yang objeknya suatu benda tertentu adalah seperti akad terhadap manfaat benda tersebut"

Objek suatu akad bisa berupa barang tertentu, misalnya jual beli, dan bisa pula berupa manfaat suatu barang seperti sewa menyewa. Bahkan sekarang objeknya, objeknya bisa berupa jasa seperti jasa broker. Maka, pengaruh hukum dan akad yang objeknya barang atau manfaat dari barang adalah sama, dalam arti rukun dan syaratnya sama.

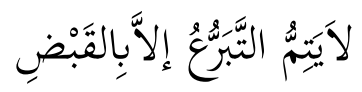

“Tidak sempurna akad tabarru' kecuali dengan penyerahan barang”

Akad tabarru' adalah akad yang dilakukan untuk kebajikan semata seperti hibah atau hadiah. Hibah tersebut belum mengikat sampai penyerahan barangnya dilaksanakan. ${ }^{23}$

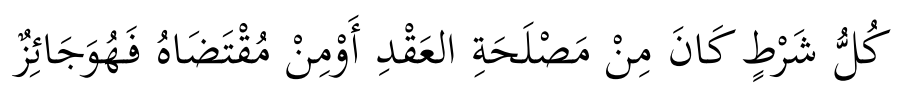

"Setiap syarat untuk kemaslahatan akad atau diperlukan oleh akad tersebut, maka syarat tersebut dibolehkan.

${ }^{23}$ Ibid., hlm. 135. 
Contohnya seperti dalam hal gadai emas kemudian ada syarat bahwa apabila barang gadai tidak ditebus dalam waktu sekian bulan, maka penerimaan gadai berhak untuk menjualnya. Atau syarat kebolehan memilih, dan yang lainnya. ${ }^{24}$

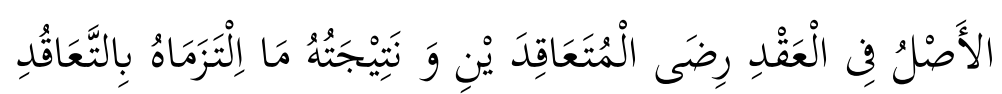

Suatu transaksi pada dasarnya harus dilandasi kerelaan kedua belah pihak dan hasilnya adalah sah dan mengikat kedua belah pihak terhadap diktum yang ditransaksikan. ${ }^{25}$

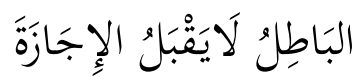

Transaksi yang batal (karena tidak memenuhi unsur syarat ataupun rukun) tidak berubah menjadi sah karena dibolehkan. ${ }^{26}$

Contohnya seseorang muslim yang berkomitmen dalam berperilaku ekonomi secara syariah melakukan transaksi keuangan dengan jasa keuangan yang menggunakan sistem bunga. Meskipun pihak jasa keuangan membolehkan dan menerima transaksi tersebut, tetapi transaksinya batal.

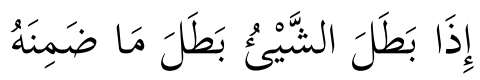

Apabila suatu transaksi batal, maka akan batal pula secara otomatis diktum-diktum dalam transaksi tersebut. ${ }^{27}$

Misalnya seseorang membeli rumah kepada pemiliknya. Ketika salah satu membatalkan transaksi pembelian rumah tersebut, maka si pembeli memulangkan rumah tersebut dan si pemilik rumah memulangkan sejumlah harga rumah tersebut.

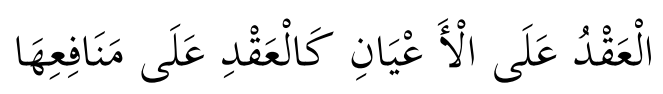

Bertransaksi dengan obyek benda, sama hukumnya dengan bertransaksi dengan obyek manfaat benda tersebut. ${ }^{28}$

\footnotetext{
${ }^{24}$ Ibid., hlm. 137.

${ }^{25}$ Ibid, hlm. 130.

${ }^{26}$ Ibid, hlm. 131.

${ }^{27}$ Ibid, hlm. 134.

${ }^{28}$ Ibid, hlm. 135.
} 
Misalnya seseorang mengontrak rumah dengan mengambil manfaat untuk tinggal atau hunian, atau membeli rumah tersebut, maka syarat dan rukunnya transaksi tersebut akan berlaku sama harus terpenuhinya.

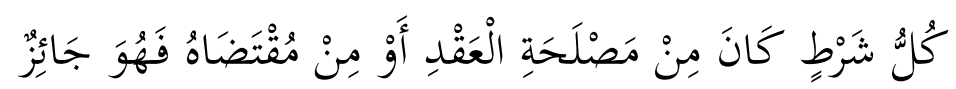

Setiap syarat dalam suatu transaksi yang bertujuan untuk kesuksesan dan tujuan transaksi tersebut, maka dibolehkan. ${ }^{29}$

Misalnya dalam jual-beli salam, bila dalam transaksi tersebut disyaratkan bahwa dana pembelian dititipkan kepada bank (pihak ketiga) sebelum serah terima barang yang dibeli untuk menghindari wanprestasi salah satu pihak, maka dibolehkan.

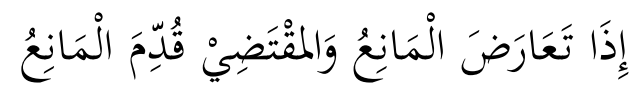

"Apabila saling bertentangan antara ketentuan hukum yang mencegah dengan yang mengharuskan pada waktu yang sama, maka didahulukanlah yang mencegah”

Kaidah diatas menegaskan bahwa apabila ada dalil atau bukti kenyataan yang bertentangan antara yang mencegah dengan yang mengharuskan pada waktu yang sama, maka didahulukan yang mencegah. Contoh : A menyewakan rumah kepada B untuk waktu 1 tahun. Kemudian sebelum habis waktu 1 tahun si A menjual rumah kepada si C. Maka si A tidak bisa menyewakan rumah kepada $\mathrm{C}$ sebelum habis kontraknya kepada si B. Dalam hal ini, yang mecegah penyarahannya adalah rumah si A yang sedang dikontrakan oleh si B, sedangkan yang mengharuskan penyerahan adalah rumah kontrakan tersebut telah dibeli oleh si C dari si $\mathrm{A} .{ }^{30}$

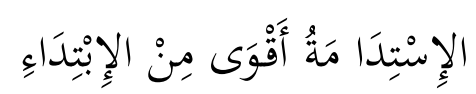

"Melanjutkan hukum yang telah ada lebih kuat daripada memulai"

Maksud kaidah ini adalah jika seorang yang memiliki suatu benda atau hak tertentu, maka benda atau hak tersebut tetap menjadi miliknya selama tidak ada buktibukti lain yang membatalkan haknya tersebut. Misalnya, ada bukti dia telah menjualnya

${ }^{29}$ Ibid, hlm. 137.
${ }^{30}$ Ibid, hlm. 175 . 
secara sah. Bahkan barang yang hilang atau dicuri orang, maka barang tersebut menjadi hak pemiliknya. Sebab, dia telah memilikinya sebelum benda itu hilang. ${ }^{31}$

\section{Kaidah-kaidah Fiqih pada Lembaga Keuangan Syariah}

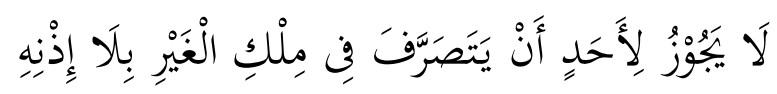

Tidak dibenarkan seseorang mendistribusikan milik orang lain tanpa adanya pemberian otoritas dari pemiliknya.

Lembaga Keuangan Syariah (LKS) adalah suatu unit jasa pelayanan keuangan yang melayani lalulintas transaksi keuangan. Transaksi baik tunai, secara angsuran, maupun Letter of Credit (LC), serta transaksi elektronik akan mendapat pelayanan secara legal bila dilakukan oleh orang atau badan hukum yang memiliki kecakapan hukum untuk bertindak hukum atau bertransaksi secara sah dan akan menolak pelayanan bertransaksi bagi pihak yang tidak memiliki hak atau tidak cakap bertindak hukum atau bertransaksi. Semisal, lembaga keuangan syariah tersebut tidak akan mentasharruf-kan (menggunakan) kepemilikan orang lain tanpa seizin pemiliknya.

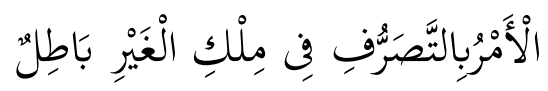

Perintah menasharrufkan (memanfaatkan) properti orang lain (tanpa izin pemiliknya) adalah batal.

Transaksi Lembaga Keuangan Syariah (LKS) dapat dikatakan sah dan legal apabila dilaksanakan oleh pihak-pihak yang secara hukum memiliki kecakapan untuk bertransaksi dan memiliki hak penuh obyek transaksi perbankan tersebut. Apabila ada suatu instruksi transaksi kepada pihak tertentu atau dengan obyek transaksi tertentu yang bukan miliknya atau bukan di bawah kekuasaannya, maka transaksi perbankan tersebut batal demi hukum.

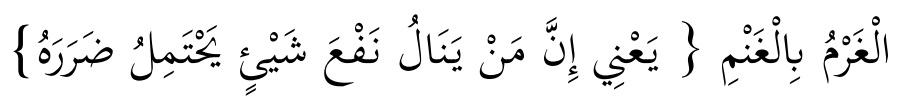

Resiko sejalan dengan keuntungan (yakni orang yang memperoleh manfaat atas sesuatu, pada saat yang sama harus mau berkorban bila terjadi resiko dari usaha

\footnotetext{
${ }^{31}$ Ibid., hlm. 176-177.
} 
yang telah memberikan keutungan kepada dirinya)

Salah satu produk lembaga keuangan syariah adalah Mudhārabah (trust financing/trust investment) yang mempunyai dua simpul yang saling berkaitan antara memperoleh keuntungan dengan sistem partnership (antara pemilik modal dan pelaku usaha) dan menanggung resiko kerugian bila usaha gagal. Kegagalan suatu usaha dalam sistem Mudhārabah dibedakan pada dua kategori; pertama, bila kegagalan usaha atau kerugian disebabkan oleh murni persaingan usaha, maka kerugian ditanggung oleh pemilik modal. Kedua, bila kerugian suatu usaha dikarenakan faktor kesengajaan oleh pelaku usaha, maka nilai ganti rugi atas kerugian usaha di tanggung oleh pelaku usaha.

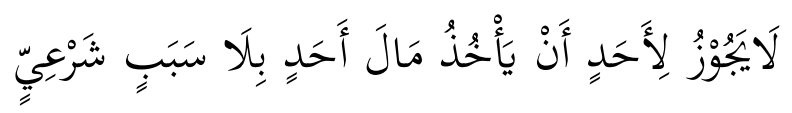

Tidak boleh bagi seseorang mengambil milik orang lain tanpa sebab syar'i.

Kaidah ini penekanan maknanya pada adanya dasar hukum syara' atau tidak adanya hukum syara' dalam pemungutan, pengambilan, pelunasan hutang dan lain semisalnya. Bila tidak ada dasar hukum syara', maka pihak manapun tidak dibenarkan untuk mengambil, memungut, menagih ataupun mengambil paksa property atau kepemilikan orang lain.

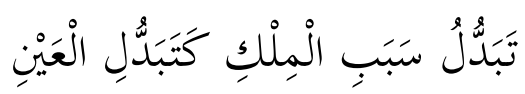

Rotasi pertukaran sebab kepemilikan sama dengan rotasi pertukaran bendanya itu sendiri. ${ }^{32}$

Misalnya, seseorang pembeli meninggal dunia, kemudian obyek pembelian/barang yang dibeli, dibeli kembali oleh pihak lain melalui ahli warisnya. Kalau nilai harganya lebih murah dari harga awal karena dikatakan cacat kepemilikan, maka tidak sah jual beli tersebut karena kepemilikan barang tersebut jelas.

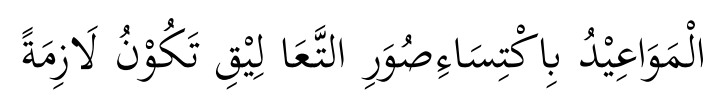

Janji yang diiringi persyaratan adalah lazim.

${ }^{32}$ Ahmad al-Nadwy, Jamharah al-Qawâid....., hlm 356. 
Produk Lembaga Keuangan Syariah (LKS) tidak jarang memberikan reward kepada nasabah berupa poin tertentu yang pada gilirannya dapat ditukar dengan hadiah tertentu untuk menarik hati nasabah berinvestasi di lembaga keuangan syariah tersebut, dengan ketentuan nasabah selalu meningkatkan saldo tabungannya. Pemberian reward menjadi kewajiban pihak lembaga bila nasabah telah melaksanakan syaratnya dengan menambah saldo tabungan dalam jumlah dan waktu tertentu sebagai persyaratan.

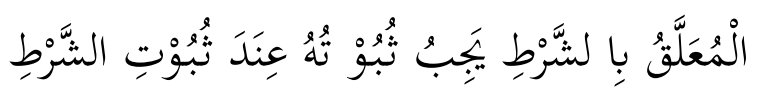

Pihak yang dibebani oleh syarat wajib memenuhinya ketika sesuatu yang disyaratkan dipenuhi.

Dalam transaksi sewa beli, pihak penyewa beli setelah melengkapi dokumen administrasi kepada pihak lembaga dengan membayar sejumlah DP (down paymant) diberikan hak untuk menempati obyek transaksi tersebut berupa sebuah rumah hunian. Pihak penyewa beli wajib membayar angsuran cicilan rumah tersebut hingga lunas, sebagai konsekuensi logis atas diktum transaksi sewa beli antara dirinya dengan sebuah lembaga. ${ }^{33}$

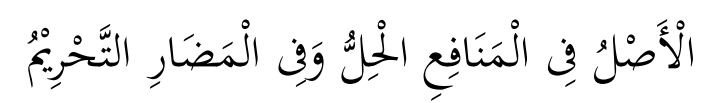

Pada dasarnya semua yang bermanfaat boleh dilaksanakan dan semua yang mendatangkan bahaya haram dilaksanakan.

Contoh produk perasuransian adalah pada produk wakalah bi al-ujrah yaitu suatu bentuk pendelegasian suatu urusan kepada seseorang atau badan usaha atau lembaga keuangan untuk berbuat sesuai yang diinginkan orang yang menyerahkan urusan tersebut, di mana orang, badan usaha atau lembaga keuangan yang mengelola urusan tersebut mendapatkan upah (manfaat). ${ }^{34}$

${ }^{33}$ Transaksi sewa-beli adalah perjanjian sewa-menyewa yang disertai dengan opsi pemindahan hak milik atas benda yang disewakan kepada penyewa setelah selesai masa sewa. Dewan Syariah Nasional (DSN)-Majlis Ulama Indonesia (MUI), Himpunan Fatwa Dewan Syariah Nasional MUI, (Ciputat: Gaung Persada, 2006), hlm. 160.

${ }^{34}$ Wakalah bi al-Ujrah adalah salah satu bentuk akad wakalah di mana peserta (pemegang polis asuransi) memberikan kuasa kepada perusahaan asuransi dalam pengelolaan dana mereka dengan pemberian upah (fee). DSN, Himpunan Fatwa Dewan Syariah Nasional MUI, hlm. 392. 


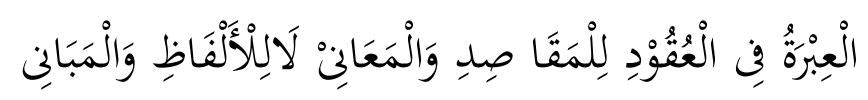

Penilain pada semua bentuk akad berdasarkan pada tujuan dan maknanya, bukan berdasarkan lafal dan bentuknya.

Suatu transaksi di lembaga keuangan syariah selalu didasarkan pada klausul cakupan akad tersebut baik yang mengikat pihak-pihak yang melakukan transaksi maupun konsekuensi yang ditimbulkan dari transaksi tersebut. Dalam kontek wadi'ah (tabungan), mulanya merupakan akad yang bersifat tolong menolong antara sesama manusia tanpa ada imbalan jasa dan tidak boleh dimanfaatkan. Tetapi karena akad wadi'ah ini mengikuti prinsip qardh dengan pengalihan akad menjadi tahawul al- 'aqd, maka implikasi hukumnya menjadi sama dengan qardh. Improvisasi produk lembaga keuangan syari'ah ini melegitimasi pengelolaannya pada lembaga keuangan syariah. Pihak lembaga juga dibolehkan untuk mengelola dana titipan nasabah (wadi'ah), kemudian dari keuntungannya dapat diberikan sebagai bonus kepada nasabah wadi'ah oleh pihak lembaga yang tidak dijanjikan dari awal.

\section{Kaidah-kaidah Fiqh tentang al-Maal (Aset Kekayaan)}

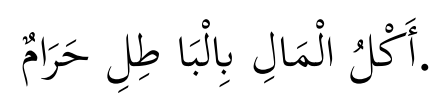

Mengkonsumsi materi yang berasal dari pendapatan yang dilarang oleh syâri'at adalah haram hukumnya. ${ }^{35}$

Contohnya membelanjakan harta dari hasil korupsi, kolusi, merampok, menipu, upah perbuatan zina, keuntungan berdagang barang haram dan lain-lain adalah haram untuk memakannya.

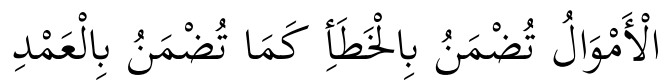

Aset kekayaan menjadi tanggungjawab seseorang untuk menggantinya manakala

${ }^{35}$ Ahmad al-Nadwy, Jamharah al-Qawaid al-Fiqhiyyah, hlm. 305. 
karena faktor kesalahan sama dengan tanggungjawabnya bila merusaknya secara sengaja. $^{36}$

Contohnya, bila seorang supir mobil rental yang merental mobil, dalam perjalanan ia menabrak atau ditabrak oleh mobil lainnya, maka ia menanggung biaya perbaikan atau mengganti mobil yang direntalnya.

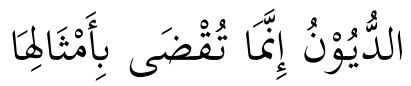

Hutang-hutang dapat dilunasi dengan (nilai barang yang dihutang) yang semisalnya (senilai). ${ }^{37}$

Contohnya bila seseorang berhutang seekor kambing jantan pada orang lain, maka ia membayar hutang tersebut dengan jenis dan spesifikasi kambing yang sama kepada pihak yang memberi piutang tersebut dan tidak harus dengan kambing yang dahulu dihutangkan kepadanya dengan catatan kambing yang dibayarkan nilainya sama.

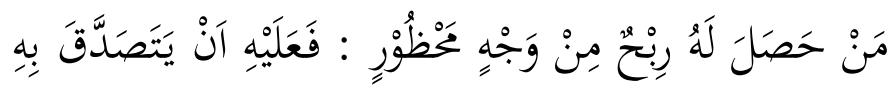

Barang siapa memperoleh keuntungan yang mengandung unsur sesuatu yang dilarang, maka hendaklah ia mengeluarkan sedekah dari keuntungan tersebut. ${ }^{38}$

Misalnya, kalau seorang pedagang pengecer yang mengambil barang dagangannya pada toko grosir mensyaratkan hanya berdagang pada kota Jakarta saja misalnya, dan ternyata pedagang pengecer tersebut berjualan barang dagangannya di kota-kota lain selain Jakarta, maka hendaklah ia bersedekah dari keuntungan yang diperolehnya.

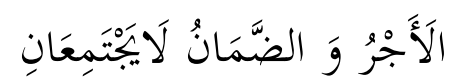

Pemberian gaji (upah) dan tanggungjawab untuk mengganti kerugian tidak dapat disatukan. ${ }^{39}$

\footnotetext{
${ }^{36}$ Ibid, hlm. 344.

${ }^{37}$ Ibid, hlm. 370.

${ }^{38}$ Ibid, hlm. 403.
} 
Contoh, bila seseorang merental mobil truk untuk angkutan barang, kemudian ia membebani muatan truk tersebut melebihi tonase yang ditentukan untuk mobil truk tersebut sehingga menimbulkan kerusakan. Maka penyewa wajib memperbaiki mobil truk tersebut dan dan tetap wajib membayar sewanya.

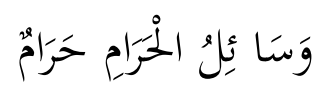

Sesuatu yang menjadi sarana suatu perbuatan yang menghantarkan kepada keharaman, maka sesuatu tersebut adalah haram hukumnya. ${ }^{40}$

Contohnya adalah menjual kondom tanpa disertai regulasi persyaratan dalam transaksi penjualan dengan menunjukkan akta nikah bagi pembeli. Maka menjual alat kontrasepsi tersebut haram hukumnya karena menjadi sarana berzina.

\section{Kaidah-kaidah Fiqih tentang arbitrase ekonomi dan penyelesaian sengketa ekonomi di lembaga keuangan syariah}

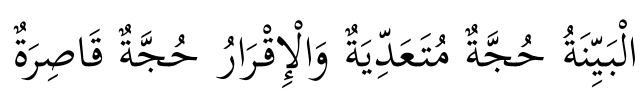

Alat bukti otentik adalah alat bukti yang mempunyai nilai pembuktian mutlak (bagi pihak-pihak yang berkepentingan), sedang ikrar (pengakuan) hanyalah bukti relatif bagi yang menyatakannya. ${ }^{41}$

Bila terjadi sengketa perdata ekonomi. Maka pihak yang memiliki bukti otentik berupa kwitansi, dokumen yang sah dari instansi terkait, faktur pembayaran atau semisal cara lisan, status alat buktinya lebih kuat dibandingkan dengan alat bukti pengakuan yang hanya dapat menguatkan gugatannya secara pribadi.

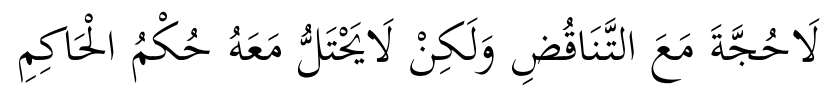

Sesuatu yang diperdebatkan tidak bisa dijadikan hujjah, tetapi juga tidak dapat menafikan keputusan hakim. ${ }^{42}$

${ }^{39}$ Musthafa Ahmad al-Zarqa, al-Madkhal al-Fiqh al-'Amm,hlm. 431

${ }^{40}$ Ahmad Al-Nadwy, Jamharah al-Qawaid al-Fiqhiyyah,hlm. 480.

${ }^{41}$ Ahmad al-Nadwy, Jamharah al-Qawâid....., hlm 423. 
Menjadikan landasan hukum dari sesuatu yang masih dalam proses debatable adalah tidak dibenarkan kecuali sudah menjadi keputusan hukum yang memiliki kekuatan yang mengikat atau in crach.

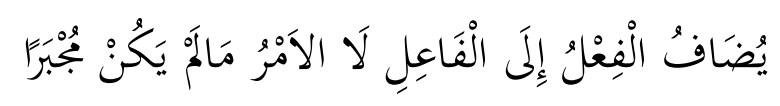

Suatu perbuatan itu dimintakan pertanggungjawaban kepada pelakunya dan bukan kepada yang memerintahkan perbuatan tersebut, kecuali pada suatu kasus yang terpaksa. ${ }^{43}$

Bila terjadi suatu wanprestasi dari suatu perjanjian antara A dan B, di mana A melakukan wanprestasi atas perintah $\mathrm{C}$ tanpa paksaan. Maka A bertanggung jawab atas wanprestasi yang ia lakukan.

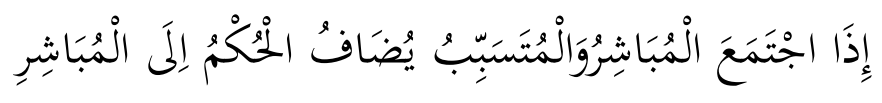

Apabila terdapat dua orang terlibat suatu perkara, yang seorang terlibat langsung dan yang lain hanya terlibat sebab-sebab, maka hukum dibebankan pada orang yang terlibat secara langsung saja. ${ }^{44}$

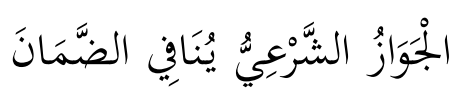

Hal yang dibolehkan syariat tidak dapat dijadikan beban/tanggungan.

Bila seorang nasabah menarik dana dari lembaga keuangan tertentu dan mendapatkan pelayanan prima dari teller dan ia memberi tip kepada teller tersebut adalah sesuatu yang dibolehkan, tetapi tidak berarti bahwa setiap penarikan dana dari lembaga tersebut, nasabah harus terus memberikan tip ke teller tersebut.

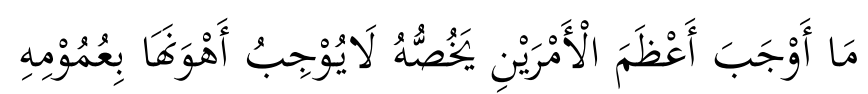

${ }^{42}$ Ibid, hlm. 424

${ }^{43}$ Ibid, hlm. 425

${ }^{44}$ Ibid, hlm. 428 
Sesuatu yang dengan karakter khususnya mewajibkan perkara yang lebih tinggi diantara dua perkara, tidak secara otomatis mewajibkan yang lebih rendah jika dilihat dari karakter umumnya. ${ }^{45}$

Sebagai contoh adalah sengketa pailit pada akad Mudhärabah, bila pailitnya usaha disebabkan oleh human error sang Mudhärib, maka ia wajib mengganti kerugian modal usaha shahib al-mal, tetapi bila pailit terjadi diluar kemampuan Mudhārib dan faktor mekanisme pasar yang mempengaruhinya, maka sanksi teringannya adalah kerugian ditanggung shâhib al-mâl sebagaimana termaktub dalam diktum akad.

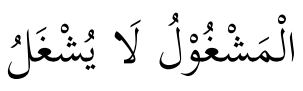

Obyek aktifitas tertentu tidak boleh dijadikan obyek aktifitas lainnya.

Sebagai contoh adalah tidak dibenarkan seseorang menggadaikan kembali barang atau benda yang sebelumnya sudah digadaikan, baik kepada penerima gadai pertama (sebagai jaminan hutang kedua) maupun kepada pihak ketiga. Begitu pula kaidah - kaidah fiqh ini berlaku untuk melarang seseorang melakukan transaksi dua kali pada satu obyek barang transaksi, seperti menggadaikan rumah sekaligus menyewakannya kemudian menjualnya sebelum masa sewa berakhir.

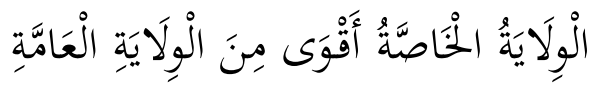

Wilayah (kekuasaan) khusus lebih kuat dari pada wilayah umum.

Dalam bidang ekonomi, kaidah - kaidah fiqh ini akan berkaitan dengan managemen wilayah (kekuasaan) yang dimiliki oleh otoritas tertentu. Misalnya General Manager suatu perusahaan lembga keuangan syariah yang berkedudukan di Indonesia, yakni di Jakarta tidak memiliki wewenang dan tidak boleh intervensi atas managemen operasional salah satu lembaganya di wilayah Jawa Barat misalnya, karena secara kewilayahan, lembaga yang berada di propinsi Jawa Barat mempunyai otoritas wilayah tersendiri yang dipegang oleh Branch Manager provinsi Barat.

\footnotetext{
${ }^{45}$ Ibid, hlm. 429
} 


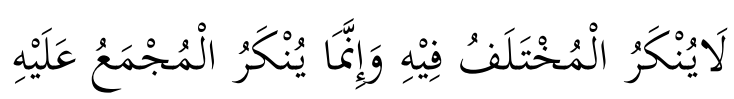

Hal-hal yang diperselisihkan tidak dapat diingkari, yang wajib diingkari adalah halhal yang sudah disepakati.

Secara lebih rinci kaidah-kaidah fiqh ini memberikan arahan kepada kita bahwa ketidakbolehan mengingkari hal-hal yang masih diperselisihkan didasarkan pada asumsi bahwa fuqaha yang berpendapat tentang haramnya sesuatu itu tidaklah lebih utama dari fuqaha yang menghalalnya.

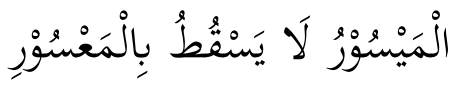

Kemampuan mengerjakan yang ringan tidak gugur kesunahannya atau kewajibannya disebabkan timbul kesulitan.

Agama Islam sebagai bentuk kasih sayang Allah Swt kepada manusia, syariatNya diciptakan sesuai dengan prototipe manusia itu sendiri. Adanya beban syari'at berupa kewajiban yang nampak berat bagi manusia, pasti disertai alternatif-alternatif tertentu yang sifatnya lebih ringan dengan tujuan agar syari'at Islam tetap dapat dilaksanakan oleh mukallaf meskipun si mukallaf tersebut dalam kondisi sulit. Contoh dalam bidang ekonomi adalah seseorang yang yang memiliki harta sampai nishab (batas kewajiban dikeluarkan zakatnya) zakat, sementara sebagian hartanya tidak berada di tangannya, maka sesuai dengan pendapat yang kuat, ia diwajibkan membayar zakat sesuai dengan jumlah harta yang berada di tangannya. ${ }^{46}$

\section{SIMPULAN}

Banyak kaidah-kaidah fikih yang berhubungan dengan masalah ibadah mahdhah, muamalah atau transaksi ekonomi. Semua kaidah tersebut dimaksudkan untuk mempermudah manusia dalam mengambil suatu keputusan terhadap hal yang baru. hlm.196.

${ }^{46}$ Muhlish Usman, Kaidah-Kaidah Ushuliyah dan Fiqhiyyah, (Jakarta : Rajawali Pers, 1993), 
Mengingat saat ini sudah semakin berkembangnya ilmu pengetahuan teknologi maupun pola pikir manusia yang mengarahkan pada permasalahan baru khususnya dalam praktek ekonomi yang harus ditemukan solusinya yang sesuai dengan kaidah fikih dan tidak bertentangan dengan ajaran Islam.

Kaidah-kaidah fiqh dibangun atas dasar kesadaran dan penelitian ilmiah dengan pendekatan induktif, yang secara sederhana dalam merumuskan suatu kaidah didasarkan pada permasalahan cabang dalam satu term tertentu dengan berbagai pendapat fuqaha, kemudian digeneralisasi dari hal-hal yang bersifat mirip atau bahkan sama dan dirumuskan dengan kalimat yang singkat dan padat makna. Konstruksi ijtihad inilah yang pada gilirannya menjadi daya akseptabilitasnya dalam mencari solusi pada permasalahan furu'iyah terkhusus bidang maliyah yang akan senantiasa muncul model baru seiring perkembangan zaman.

Kaidah-kaidah fiqh dalam bidang ekonomi bertugas menjustifikasi dan melegitimasi seluruh aktifitas ekonomi umat Islam dalam berbagai bidang transaksi ekonomi, baik yang terkait dengan transaksi-transaksi mono-akad maupun multi-akad. Transaksi mono-akad atau akad tunggal seperti jaul-beli, sewa-menyewa, gadai, hutang piutang pada gilirannya sesuai kebutuhan aktifitas ekonomi masyarakat kontemporer, memerlukan transaksi multi-akad. Sebagai contoh maraknya masyarakat melakukan transaksi sewa beli kendaraan bermotor, perumahan, barang elektronik dan yang lainnya. Maka kaidah-kaidah fiqh yang menjustifikasi adalah yang berkaitan dengan transaksi al-ijarah muntahiyah bi al-tamlîk atau lebih dikenal dengan IMBT. Demikian seterusnya pada permasalahan ekonomi lainnya di lembaga keuangan syariah menjadi sah dengan menggunakan qawaidh fiqhiyyah (kaidah-kaidah fiqih) atau dhawabith fiqhiyyah. 


\section{DAFTAR PUSTAKA}

Dahlan, A.R. (2011). Ushul Fiqih. Jakarta: Amzah.

Ad-da'asi, A.U. (1989). al-Qawaid al-Fiqhiyyah ma'a syarhi al-Mujaz, cet. 3, Damaskus: dar at-Tarmizi.

Al-Nadwy, A. (2000). Jamharah al-Qawâid al-Fiqhiyyah, Damakus: Dar al-kalam.

Al-Sayid, M.A. (1996). Tafsir ayat al-Ahkam, Bayrut: Dar al-Fikr.

Al-Zarqa, M.A (1989). Syarhu al-Qawaid al-Fiqhiyyah, cet. 2 Damaskus: Dar alQalam.

Andiko, T. (2011). Ilmu Qawa'id Fiqhiyyah : Panduan Praktis dalam Merespon Problematika Hukum Islam, Yogyakarta : Teras.

Antonio, M.S. (2001). Bank Syari'ah dari Teori ke Praktek, Jakarta: Gema Insani.

Arfan, A. (2013). 99 Kaidah Fiqh Muamalah Kulliyah, Malang: UIN Maliki Press.

Dahlan, A.A. (1997). Ensiklopedi Hukum Islam, Jilid IV, Jakarta: Ichtiar Baru van Houve.

Djazuli, A. (2006). Kaidah-Kaidah Fikih : Kaidah-Kaidah Hukum Islam Dalam Menyelesaikan Masalah-Masalah Yang Praktis, Jakarta : Kencana.

Dewan Syariah Nasional (DSN)-Majlis Ulama Indonesia (MUI), 2006.

Ismail. (2011). Perbankan Syari'ah, Jakarta : Kencana Media Group.

Muhamad. (2000). Sistem dan Prosedur Operasional Bank Syariah, Yogyakarta: UII Pres.

Mujib, M.A. (1994). Kamus Istilah Fikih, Jakarta: Pustaka Firdaus Wiroso, 2005, Jual Beli Murabahah, Yogyakarta: UII Press.

Rahman, A.A. (1976). Qa'idah-Qa'idah Fiqih (Qawa'idul Fiqhiyyah), Jakarta: Bulan Bintang.

Usman, M. (1993) Kaidah-Kaidah Ushuliyah dan Fiqhiyyah, Jakarta : Rajawali Pers.

\section{Jurnal}

Sulistiani, S.L. (Maret, 2018). Perbandingan Sumber Hukum Islam, TAHKIM, Jurnal Peradaban dan Hukum Islam. Vol. 1, No. 1, Hal 114. 


\section{Internet}

http://www.psycholovegy.com/2012/05/pengertian-dan-ruang-lingkup-fiqh.html diakses tanggal 20 januari 2020 
